\title{
HRM in Relation To Employee Motivation and Job Performance in the Hospitality Industry
}

\author{
Andries J. du Plessis, Nalinh Douangphichit, Patrick Dodd \\ Department of Management and Marketing, Unitec New Zealand, Auckland, New Zealand
}

\section{ABSTRACT}

2016 Research Leap/Inovatus Services Ltd. All rights reserved.

DOI: $10.18775 / j i b r m .1849-8558.2015 .14 .3002$ URL: http://dx.doi.org/10.18775/jibrm.18498558.2015.14.3002

Keywords:

Motivation,

Job satisfaction,

Performance,

HRM practices

\begin{abstract}
Purpose:
The hospitality industry refers to organisations that provide accommodation and food services for people when they travel. The hospitality industry is also known as a "people business". The hotels and catering organisations underperform, still deliver inadequate services, and provide limited facilities compared to similar businesses in the same region. This can have a negative impact on the tourism industry in Laos. HRM potentially contributes to employee work performance in the organisation. The performance of employees in hotel organisations can be judged or measured by their attentiveness, their friendliness, their appearances, their attitudes, and the way they carry out and perform their assigned tasks. Most of the respondents feel that their organisations create the conditions whereby they are motivated to work harder. The hotel industry recognises the importance of training in relation to their work performed. The main factor that brings about high level of job satisfaction and motivation is salary.
\end{abstract}

\section{Introduction}

Organizations do not exist if there are no people or employees. The organizations employ all resources such as human, physical and financial resources to produce expected results. To have success, and maintain the success, every organization demands extraordinary abilities and sustained efforts from its employees and people. Rao (2008) claims that when employees work to the best of their abilities and do their work with passion, enthusiasm and high commitment the business will grow significantly and continuously. In general, every organization has pretty much the same kind of resources such as land, buildings, materials, equipment, and finance to work with, but the only element that differentiates between business organizations is the HR factor.

If the organizations use and employ its human resource to the best potential advantage, there is very little that can stop the organization achieving its goals and objectives. Thomas J. Watson, the founder of IBM states, "you can get capital and erect buildings, but it takes people to build a business" (Snell \& Bohlander, 2012, p. 1). Jack Welch, the former director of General Electric also believes that human resources are the backbone of the organization due to the fact that they develop and use technology, they contribute great ideas for product development and deliver superior customer services, they collect, analyze and distribute information, and they create and execute strategy (Rao, 2008). When employees are motivated and inspired, they will be fully involved in organizational activities and work to their maximum potential. This can assist a company to achieve its goals and attain results rapidly, efficiently and effectively.

Employee satisfaction refers to "a pleasurable or positive emotional state resulting from the appraisal of one's job or job experiences" Grigoroudis \& Siskos, 2010, p. 72). Employee satisfaction is one of the important drivers for organizational success. Du Plessis (2015), and Nel et al. (2014) assert that identifying the key factors that motivate employees at work is necessary for the organization to recognize and understand the key motivational factors that influence their employees' behavior and action can be taken to help the organization create appropriate and suitable strategies to motivate their employees to perform work at a high level. In addition, Stone (2013) claims that knowing how to motivate employees can help the organization to increase productivity and improve customer service and is one factor that creates a competitive advantage over competitors.

The hospitality industry refers to organizations that provide accommodation and food services for people when they travel 
away from their homes. The hospitality industry is also known as a "people business". The people in this context refer to both employees who deliver the products and services, and to customers who consume them. Similar to other organizations, hospitality organizations need employees with different kinds of knowledge, skills, and experience to provide a high quality of products and services that are needed by customers.

In other words, hospitality business operations depend on a capable and service-oriented labor force (Nickson, 2013). It is necessary for the hospitality industry to have effective HR functions such as job analysis, employee selection, training and development, compensation management and motivational schemes that are integrated or linked with its strategic plans or goals in order to improve organizational performance standards, deliver quality service to customers, and maintain its competitiveness in the pursuit of organizational success (Darwish, 2013; Holbeche, 2012). This research project mainly focuses on overall HRM functions such as employee motivation and satisfaction, which is practiced by HR managers in hotels in Laos.

\section{Problem Investigated}

Since Lao People' Democratic Republic opened its country to foreign tourists in 1989, the tourism and hospitality industry has grown and developed quickly and has become one of the largest industries in Laos. Due to an increase in the importance of tourism and the support from the government, the hospitality business such as the hotels and restaurants grew significantly since 1995 and has increased dramatically comparing to other main sectors in the Lao economy. The growth rate of hotels more than tripled between 1992 and 1997, and the amount of foreign investment in the hospitality industry has grown continuously (Yamauchi \& Lee, 1999).

However, when compared with regional and international competitors, the hospitality businesses, especially hotels and restaurants in Laos are still considered as small and medium sized enterprises (SMEs). These businesses in Laos still underperform in relation to HR development and training. They do not have the capability to operate effectively and efficiently. As a result, this might hinder the hospitality business and tourism industry in Laos that is planned to grow considerably over coming years (Sustainable Tourism Development Project In Lao PDR, 2009).

The number of hotels and restaurants is increasing considerably and the foreign investment rates are rising substantially. This contributes towards a higher level of competition in the hotel and service business in Laos. The hotels and catering organizations underperform, still deliver inadequate services, and provide limited facilities compared to similar businesses in the same region. This can have a negative impact on the tourism industry in Laos.

Therefore, the main research problem is: What are the practical and suitable HRM practices that would increase employee motivation, satisfaction and job performance in the hotel industry in Laos?

\section{Research Objectives}

1. The major objective of this research project is to identify and determine practical and suitable HRM practices for employee job performance, employee motivation, and employee satisfaction to support the hotel industry in Laos, and enabling it to have a competitive advantage, attain goals and sustain business.

2. To identify factors that motivates hotel employees to perform at a high standard.

3. To determine factors that brings about a high level of job satisfaction among employees in order to engage employees to achieve organisational goals and reduces the rate of employee turnover in hotels in Laos.

4. To examine the influence of training on an employee's work performance in the Lao hotel industry.

5. To identify the impact of the financial incentives implemented by the organisation on employee performance.

6. To determine the relationship between satisfaction of employees and the salary paid by the organization.

\section{Literature Review}

Looking back to the development of HR practices, in the early 1970s, there was only a department called personnel department which involved the workforce in the organisation. In the late 70s, the world economy changed steadily and organisations began to consider the labour force as an important resource for their business activities and operations. The concept of human resource management (HRM) began in the 1980s and this concept grew and developed over the next decade (McGuire \& Jorgensen, 2010). Over the last 30 years, HRM has attracted attention across many fields due to its contribution to the effectiveness and efficiency of employee management (Nickson, 2013). In today's global economy, organisations are operating in a dynamic and fast changing environment. In order to maintain competitive advantage, achieve organisational strategic goals, and adapt and change to respond quickly to market needs and demands, it is vital for contemporary organisations to have HR professionals or HR managers who have sophisticated and advanced HRM skills and knowledge (Du Plessis, 2015).

\section{The role of HR managers in employee work performance}

Boxall and Purcell (2011) assert that HRM potentially contributes to employee work performance in the organisation. The quality of employee work performance is reliant on a function of ability, motivation and opportunity. This means HR managers intervene to develop employee ability, motivation and opportunity in order to maximise work performance in the organisation. Motivation refers to external and internal factors that influence employees to perform a particular task or job well. One of the roles of HR managers is to maximise the level of employee motivation. Wilton (2011) points out that it is necessary for HR managers to design jobs, implement practices, conduct procedures, and create a work environment to stimulate 
and encourage employees to perform to their full potential in the way desired by the organisation. HR managers should understand intrinsic and extrinsic factors such as the financial incentive, recognition, job satisfaction and achievement that motivate workers and unlock the power of discretionary effort in them. HR managers should pay attention to reconcile the mutual interests or mixed motives of companies and workers, and make sure both employers and employees have sufficient levels of the mutual relationship in order to maintain and sustain stability of work performance.

HRM refers to all those activities including recruiting, designing work for, training and developing, appraising and rewarding, guiding, and motivating employees in the organization. In other words, HRM is the framework of strategies, policies, procedures and practices for managing the relationship between employers and employees (Du Plessis, 2015).

\section{Training improving employee performance}

Training is defined as "the process of developing a staff member's knowledge, skills, and attitudes necessary to perform tasks required for a position" (Hayes \& Ninemeier, 2009, p. 172). Training and development can influence organisational performance also in the hospitality industry (Aksu, 2005; Boella $\&$ Goss-Turner, 2012). This study is examining the influence of relevant training programmes that employees should receive in order to develop their capacity of their work performance. If the organisation does not have an effective training and development programme, it will fall behind in terms of the skill sets and knowledge required for competitive advantage. Hayes and Ninemeier (2009) point out that only by continually upgrading the skills of employees it can help the organisation to achieve and maintain its competitive advantage. Training and development is a big challenge that every organisation should address. Loedolff, Erasmus, Van, Mda, and Nel (2013) are of the opinion that the rapid changes in advanced technology in today's workplace alter the way in which work is performed. Training is an investment in the labour force which helps to position itself for achievement in the future in any hospitality organisation. The main purpose of training is to provide the workforce with the necessary skills and knowledge required to perform a job effectively and job training is an ongoing process that prevents obsolescent $\mathrm{HR}$ in the organisation and increase organisational productivity.

\section{Employee motivation increasing employee performance}

Factors that motivate hotel employees to perform at high standard levels are discussed in the literature in this section. Employee motivation is not a new topic in HRM and it has been defined by prominent scholars in various fields and many of them give different definitions to employee motivation. However, many of these definitions have similar ideas and notions. From the studies of the economy, psychology, and human resources, motivation refers to reasons or factors that encourage, or make people behave in a particular way (Bratton \& Gold, 2012; Nelson \& Quick, 2012).
From this viewpoint, an individual can be affected by many different drivers such as a desire for an object, or basic needs such as food and water. Motivation also refers to the intrinsic and extrinsic elements that influence an individual to act in certain ways or take certain actions (Nahavandi, Denhardt, Denhardt, \& Aristigueta, 2014; Pinder, 2014). Motivation is a force (either intrinsic or extrinsic) that makes people do what they do. This means individual motivation is influenced by both internal factors (including personal needs and expectations) and external factors (organisational reward and compensation). In the context of HRM, motivation is critical to the organisational performance. The organisation can motivate their employees to work harder and be involved in achieving organisational goals. Motivating employees is about using different significant factors to influence them in the manner that makes them feel motivated to perform their tasks with their best effort, boost their productivity levels, or carry out their tasks at a high standard.

Prominent scholars in different fields have developed many motivation models, and all of those motivation models aim to identify and explain forces and drives that can also be employed to motivate people in the hospitality industry (Beardwell \& Claydon, 2007). There are many reasons why organisations continually focus on motivating employees.

The first reason is motivated employees tend to work with their best effort and do more than is required of them. This can help the organisation to increase its productivity.

The second reason is motivated employees are likely to work effectively, get work done on time to a high quality and within budget. This can help the organisation minimise its operational cost and its labour cost and in turn increase its profitability.

The third reason is that the level of staff turnover may to some extent be reduced if the staff is motivated to perform their tasks.

Another reason why the organisation puts more effort into motivating employees is that an organisation with a motivated workforce introduces change earlier than the organisation where its employees are demotivated (Ghuman, 2010; Nahavandi et al., 2014). From a general perspective, each individual can be motivated. However, each individual is not motivated or influenced by "the same things, at the same time, for the same reasons, or with the same intensity" (Nel et al., 2014).

Thus, it is important for every HR manager or hotel management to learn and understand the various motivational theories and know how to apply them in different situations and conditions In HRM terms, there are many different motivation models that the hospitality industry and HR managers who work in the hotel industry should know, understand and apply, and for this paper (due to length limitation) the researchers only mention the relevant motivation theories: Maslow's Need Hierarchy theory, Herzberg's two-factor theory, Theory $\mathrm{X}$ and Theory Y, Alderfer's ERG theory, McClelland's three-need theory, and intrinsic and extrinsic of motivation in order to able to motivate 
hotel employees to do their jobs and enjoy their work (Armstrong \& Taylor, 2014; Nahavandi et al., 2014). A better understanding of all forms of employee motivation can help hotel managements enhance and implement motivation of employees more effectively and then effective employee motivation will help to boost employee performance and improve service quality directly and indirectly such as competitive advantage.

\section{Intrinsic and extrinsic motivation}

Many scholars claim that an individual is motivated to do what they do by extrinsic and intrinsic factors. This means an individual can be motivated or driven by forces within an individual or forces outside an individual. Motivation can be generated from inside the individual. This is known as intrinsic motivation (Gerson, 2006). For example, if an individual has a strong desire to achieve some goals or do something in order to accomplish such desire or goals, an individual has to act in some particular way to help him/her reach such desired goals. Intrinsic motivation is a form of self-actualisation in which a person needs to accomplish something worthwhile. In other words, it is selfgenerated or self- motivated and is free from financial rewards.

Motivation can also stem from outside the person and influences their behaviour and actions and is known as extrinsic motivation. When applying the idea of extrinsic motivators to a working context, it is clearly seen that this kind of factor influences most employees to come to work as the employees think that their work as the main source of income (Neely, 2007; Pullins, Haugtvedt, Dickson, Fine, \& Lewicki, 2000). The organisation should try to create a link between intrinsic and extrinsic motivation. This is because only providing employee rewards and standard employment benefit packages cannot motivate employees to devote their best effort and produce a good performance in the long run.

\section{Employee motivation in hospitality industry}

The performance of employees in hotel organisations can be judged or measured by their attentiveness, their friendliness, their appearances, their attitudes, and the way they carry out and perform their assigned tasks. St-Onge, Morin, Bellehumeur, and Dupuis (2009) add that the good performance in hotel organisations should create a high level of customer satisfaction. As a result, customer will go back and use the hotel goods and services again. Watson (2008) postulates that the success of the hotel relies on how well they manage and motivate their employees but there are many factors that make it difficult to motivate employees in hotels. The first factor is that the pay in hotel organisations is the minimum wage rate or the hotel organisations only pay what is required by the labour law to employees. This may not meet or satisfy the basic needs of many front-line employees. The second factor is many hotel organisations, particularly small and medium sized hotels seem to hire employees of a certain age. Some of the hotels prefer to hire younger employees over the older ones, while some of them prefer to hire older staff over the younger ones. This can make the employees who are in an unfavourable age group not perform at their best efforts because they think that they are not being fairly and equally treated (Josten \& Schalk, 2010).

\section{Job satisfaction influencing employee performance}

Job satisfaction is defined as "the attitudes and feelings people have about their work. Positive and favourable attitudes towards the job indicate job satisfaction. Negative and unfavourable attitudes towards the job indicate job dissatisfaction" (Armstrong, 2006, p. 264).

Typically, morale is also known as job satisfaction. Morale occurs when employees feel their needs are satisfied or when they feel they achieve something that have importance and value recognition in the workplace. Morale or job satisfaction declines when there is more demanding and stressful work, fewer relationships with top management, and insufficient compensation and other rewards (Mathis \& Jackson, 2011). Wicker (2011) also points out that job satisfaction brings pleasant feelings that normally results in a positive work attitude and a greater level of performance. A satisfied employee seems to be more flexible, innovative, creative, and loyal. Mathis and Jackson (2011) add that "employee job satisfaction influences organisational commitment and performance which in turn affects employee retention and employee turnover" (p. 54). For workers to stay with the company, they need to feel satisfied with their work and committed to the company. There is a relationship between job satisfaction and employee performance. Saiyadain (2003) and Robbins et al. (2007) assert that it is clear that satisfied or happy employees are more motivated and productive than dissatisfied employees. It appears that satisfaction results in devoting more effort by workers and consequently contributes to higher levels of work performance. Workers who are dissatisfied seem to be absent from work, but workers who are happy with work and think their work is important tend to be less absent.

\section{Factors influencing job satisfaction in the workplace}

There are several factors that affect job satisfaction in the workplace. The first factor that influences job satisfaction is the reward system. Du Plessis, Toh, and Chen (2013) claim that there is a relation between job satisfaction and the organisational reward system and reward schemes such as pay, benefits, promotions and other financial benefits greatly contribute to job satisfaction in the workplace. Job satisfaction improves when pay and promotion are seen as fair and reasonable; equal pay for equal work and fairness in promotion. The second factor that influences job satisfaction is the work itself. The nature of work leads to the feeling of satisfaction. Autonomy, flexibility, and discretion of job can heavily contribute to job satisfaction (Chandan, 2009). On the contrary, role and task ambiguity, confusing guidelines, and limited and unclear understanding of the job can result in job dissatisfaction (Mishra, 2009). The next factor that affects job satisfaction is supervisory behaviour. Job satisfaction appears to be higher if workers believe and feel that 
their immediate supervisors or their bosses are competent, treat them with respect, dignity, and courtesy (Macky \& Wilson, 2013). Employees feel satisfied when their supervisors or bosses provide constructive advice to them, has interest in their welfare, listen to their opinions, are friendly, and are willing to help and support them.

Another factor that influences satisfaction is working conditions that can result in physical comfort such as the degree of job satisfaction: a clean and tidy workplace, safety in the workplace, air conditioning, heating system, lighting, level of noise, tools and equipment for work performance. In conclusion, job satisfaction can derive from job autonomy, opportunities for personal and professional growth through training and promotion, clear responsibility for tasks, good pay and benefits, performance recognition, working conditions, supervision, and good relationship with managers and co-workers (Mathis \& Jackson, 2011; Özbilgin et al., 2014).

\section{Research Methodology}

The quantitative research approach is "explaining phenomena by collecting numerical data that are analysed using mathematically based methods (in particular statistics)" (Muijs, 2010 , p. 1). This means a quantitative research approach is usually used to gather numerical data from physical and social activities such as actions and conversations, and then employs statistical measurements, mathematical models, and computational techniques to analyse those numerical data directly relating to the phenomena. It is grounded on a deductive theory in which the researcher tests and measures hypotheses against the existing theories.

Qualitative research methods are clearly different from quantitative research methods. This is because qualitative research methods mostly focus on collecting words, pictures, and objects rather than numbers. Cohen, Manion, and Morrison (2013) and Cho and Trent (2006) point out that unstructured or semi-structured techniques such as in-depth individual interviews, media analysis, focus groups, and observations are typical data collection methods in qualitative research. In addition, the data from qualitative research such as words, pictures, and objects are frequently analysed without the use of statistics.

\section{Sample Selection}

The researcher applies a probability sampling method in which every unit in the study population has an equal opportunity of being selected. By weighting sampled units according to their probability of selection can help the researcher to accurately determine samples. The researcher has sent request letters to most of the three to five star hotels in Vientiane, Laos. This means most three to five star hotels have equal opportunities to participate in this research project if they are interested. In relation to sample size, these six hotels represent the whole hotel industry in Laos in relation to HRM practices. This is because the six participated hotels are amongst the biggest hotels in Laos and there is not much variance in this kind of business.

Each HR manager from each targeted hotel was interviewed in order to seek to understand their HRM skills and their HRM practices. This helped the researcher to obtain sufficient and detailed information to support the research objectives which relate to employee training. In addition to qualitative data collection, quantitative data collection is applied to collect numeric data, and 100 employees from six hotels were sufficient as group representatives. A total of 100 respondents provide sufficient information relating to employee motivation and satisfaction in the hotel industry. In addition, 100 respondents are sufficient for statistical analysis in SPSS software.

\section{Pilot Study}

The researcher has carried out a small scale pilot survey in order to test the questionnaire and to make sure that (1) the questionnaire is clear and understandable, (2) the answers obtained from the questionnaire addresses the research objectives, and (3) language use in the questionnaire is clear and correct.

\section{Data Collection}

Primary data are those that are collected afresh, for the first time, and from the beginning to end. Primary data are also known as original data collected from the source of origin and in the process of investigation. There are several ways to obtain this kind of data such as observation method, interview method, through questionnaires, and through schedules (Kothari, 2011).

Secondary data are defined as the data that have already been gathered and analysed by some other scholars or researchers. In other words, secondary data are those that already have been collected by other researchers or scholars and that already have been processed through the statistical analysis (Kothari, 2011).

The main data for this research project is gathered in Lao PDR which is the home country of the researcher. As the majority of Lao people speak Lao as an official language and not many people speak English, the research instruments such as the questionnaire and the interview transcripts are prepared in both English and Lao.

Both quantitative and qualitative research methods (also known as the mixed research methods) are employed for data collection in this research study. Mixed research methods are the approaches that integrate both quantitative methods (designed to collect numerical information) and qualitative methods (designed to collect words or narrative information) for collecting and analysing data, combining the findings, and drawing conclusions in one single research study.

\section{Questionnaire data collection}

The first method of data collection is employing selfadministered or self-completion questionnaires to explore 
opinion and experience about employee training, work satisfaction and motivation of employees in the six selected hotels in Laos. In the self-completion questionnaire, many of the questions are designed and developed for employees in hospitality organisations. Participants are randomly selected. They can be any employees from any level, such as chef, room service staff, housekeepers, front desk staff, bellhops, van drivers, pool attendants, and so on in the selected hotels, and who are willing to answer a series of questions. The interested questionnaire participants come from any level in the selected hotels because this is strictly voluntary participation. It is important to note that HR managers and hotel managers were not allowed to be involved in the questionnaire; they fully participated in the interviews only. To guarantee that the questionnaire addresses the objectives of this research project, the researcher has formulated 29 questions and all of them are closed-ended questions.

\section{Interview data collection}

In this study, the researcher employs only semi-structured interviews as a second method of data collection. In the semistructured interview approach, open-ended questions are formed and the researcher only chooses people who are in positions such as HR managers in selected hotels in Laos. As they are HR managers who work or get involved directly with the job that relates to or identifies with the research topic, they can supply indepth, accurate and precise information.

\section{Data Analysis}

After raw data has been collected, the data analysis task is undertaken. Data analysis is the practice of evaluating data employing analytical and logical reasoning to examine and interpret each piece of raw data (Business Dictionary, 2014). Data analysis is the translating and interpreting process used to answer the research question(s) and is the most demanding and skilled task in the research process as it requires the researcher's own judgement and skill. Thus, in this research study, the researcher classifies data into two categories which are (1) quantitative data collected through questionnaires and (2) qualitative data collected from interviews. Then, the researchers used many different tools and approaches to analyse the data. In relation to data analysis, text coding, content analysis, thematic analysis, narrative analysis, and comparative analysis have been used to analyse qualitative data whereas SPSS software has been used to analyse quantitative data.

\section{Analysis Of The Results}

In question one, participants are asked to provide their gender. The result of this question showed that more males than females participated in the survey. The total number of respondents is 105, and there are 46 female and 59 male respondents. This means, of 105 respondents, female respondents occupy 55\%, whereas male respondents account for $45 \%$.
Table 1: Participant age

\begin{tabular}{|c|c|c|}
\hline Age bracket & Frequency & Percent \\
\hline $18-28$ & 50 & $47.6 \%$ \\
\hline $29-39$ & 37 & $35.2 \%$ \\
\hline $\begin{array}{l}40 \text { and } \\
\text { more }\end{array}$ & 18 & $17.2 \%$ \\
\hline Total & $\mathbf{1 0 5}$ & $\mathbf{1 0 0} \%$ \\
\hline
\end{tabular}

Table 2: Work experience

\begin{tabular}{|c|c|c|}
\hline Work experience & Frequency & Percent \\
\hline Less than 1 year & 22 & $21.0 \%$ \\
\hline 2-5 years & 39 & $37.1 \%$ \\
\hline 6-10 years & 16 & $15.2 \%$ \\
\hline 11-15 years & 19 & $18.2 \%$ \\
\hline $\begin{array}{l}\text { More than 15 } \\
\text { years }\end{array}$ & 9 & $8.6 \%$ \\
\hline Total & $\mathbf{1 0 5}$ & $\mathbf{1 0 0 . 0 \%}$ \\
\hline
\end{tabular}

In question four, participants were asked to state their level of education. The majority of participants $(50.5 \%)$ have a High School Certificate for the highest education level, followed by the participants who achieve Vocational School Diploma, College Diploma and Bachelor degree which cover 20\%, 10.5\%, and $18 \%$ respectively with only $1 \%$ a Master degree and no Doctoral.

In question six, participants were asked about their overall satisfaction in their current job. The choice was of one of two options which are 'yes' or 'no'. A total of $60 \%$ are satisfied with their current job, whereas $40 \%$ are not satisfied with their current job.

Table 3: Participant's satisfaction with their current job (Q6)

\begin{tabular}{|l|l|l|l|l|c|}
\hline \multicolumn{2}{|c|}{} & Frequency & Percent & $\begin{array}{l}\text { Valid } \\
\text { Percent }\end{array}$ & $\begin{array}{l}\text { Cumulative } \\
\text { Percent }\end{array}$ \\
\hline Valid & Yes & 63 & 60.0 & 60.0 & 60.0 \\
\cline { 2 - 6 } & No & 42 & 40.0 & 40.0 & 100.0 \\
\hline
\end{tabular}

In question 7, participants were asked about their satisfaction in their current organisations by using a scale from 1 to $5(1=$ strongly disagree, 2 = disagree, $3=$ neither agree nor disagree, 4 $=$ agree, and $5=$ strongly agree. The findings are shown in Table 4. 
Table 4: Opinions about staff satisfaction in their current organization (Q7)

\begin{tabular}{|c|c|c|c|c|c|c|}
\hline & $\begin{array}{c}\text { Dis } \\
\text { agr } \\
\text { ee } \\
\text { str } \\
\text { on } \\
\text { gly }\end{array}$ & Disagree & $\begin{array}{l}\text { Neither } \\
\text { agree } \\
\text { nor } \\
\text { disagre } \\
\text { e }\end{array}$ & Agree & $\begin{array}{c}\text { Agree } \\
\text { strong } \\
\text { ly }\end{array}$ & \\
\hline & (1) & (2) & (3) & (4) & (5) & \\
\hline $\begin{array}{l}\text { 1)I am } \\
\text { satisfied } \\
\text { with the } \\
\text { organizat } \\
\text { ional } \\
\text { working } \\
\text { culture }\end{array}$ & $\begin{array}{c}3.8 \\
\%\end{array}$ & $8.6 \%$ & $13.3 \%$ & $\begin{array}{c}55.2 \\
\%\end{array}$ & $19.1 \%$ & $100 \%$ \\
\hline $\begin{array}{l}\text { 2)I feel } \\
\text { my work } \\
\text { is } \\
\text { meaningf } \\
\text { ul to me }\end{array}$ & $0 \%$ & $1.9 \%$ & $13.3 \%$ & $\begin{array}{c}54.3 \\
\%\end{array}$ & $30.5 \%$ & $100 \%$ \\
\hline $\begin{array}{l}\text { 3)I am } \\
\text { satisfied } \\
\text { with the } \\
\text { supervisi } \\
\text { on of my } \\
\text { immediat } \\
\text { e } \\
\text { superviso } \\
\text { r }\end{array}$ & $\begin{array}{c}2.9 \\
\%\end{array}$ & $8.6 \%$ & $18.1 \%$ & $\begin{array}{c}36.2 \\
\%\end{array}$ & $34.3 \%$ & $100 \%$ \\
\hline $\begin{array}{l}\text { 4)My } \\
\text { organizat } \\
\text { ion pays } \\
\text { me well } \\
\text { for the } \\
\text { work. }\end{array}$ & $\begin{array}{c}5.7 \\
\%\end{array}$ & $21.9 \%$ & $18.1 \%$ & $\begin{array}{c}41.9 \\
\%\end{array}$ & $12.4 \%$ & $100 \%$ \\
\hline $\begin{array}{l}\text { 5)I am } \\
\text { satisfied } \\
\text { with my } \\
\text { employm } \\
\text { ent } \\
\text { benefits }\end{array}$ & $\begin{array}{c}4.8 \\
\%\end{array}$ & $24.8 \%$ & $21.9 \%$ & $39 \%$ & $9.5 \%$ & $100 \%$ \\
\hline $\begin{array}{l}\text { 6)I am } \\
\text { happy } \\
\text { with my } \\
\text { job } \\
\text { overall } \\
\end{array}$ & $\begin{array}{c}2.9 \\
\%\end{array}$ & $6.7 \%$ & $18.1 \%$ & $40 \%$ & $32.3 \%$ & $100 \%$ \\
\hline
\end{tabular}

According to the information in Table 4, 55.2\% of respondents agree that they are satisfied with the organisational working culture. In the second statement, $54.3 \%$ and $30.5 \%$ of respondents agree and strongly agree that they feel their work is meaningful to them. In the third statement, $36.2 \%$ and $34.3 \%$ agree and strongly agree that they are satisfied with the supervision of their immediate supervisors. In the fourth statement, $41.9 \%$ of respondents agree that their organisations pay them well for the work, and in fifth statement $39 \%$ of respondents agree that they are satisfied with their employment benefits. In the last statement, $40 \%$ and $32 \%$ of respondents agree and strongly agree that they are happy with their overall job. In question 12, participants were asked to state to what extent they have received appropriate rewards on the job for performance recognition and the findings are: $72.4 \%$ of respondents sometimes feel that they receive appropriate rewards on the job for performance recognition, followed by those who always feel that they receive appropriate rewards on their job performance, which accounts for $11.4 \%$. It is interesting to note that $3.8 \%$ of respondents seldom, or never feel that they receive appropriate rewards for their performance, while $8.6 \%$ of them are not sure about whether they receive appropriate rewards on their job performance or not.

In question 14, participants were asked about the factors that contribute to their job satisfaction and the majority of respondents view salary as the main factor that makes them satisfied with their job, $(26.8 \%$ ) with $18.4 \%, 16.6 \%$, and $12 \%$ of respondents that think job security, friendly working environment, and varied work assignments are the other influential factors that make them satisfied with their job, while $8.3 \%, 7.8 \%$, and $6.9 \%$ of them perceive that training opportunities, interesting jobs, and retirement benefits as the influential factors that make them satisfied with their job. Only $3.2 \%$ of the respondents see promotional opportunities as the factor that influences their job satisfaction.

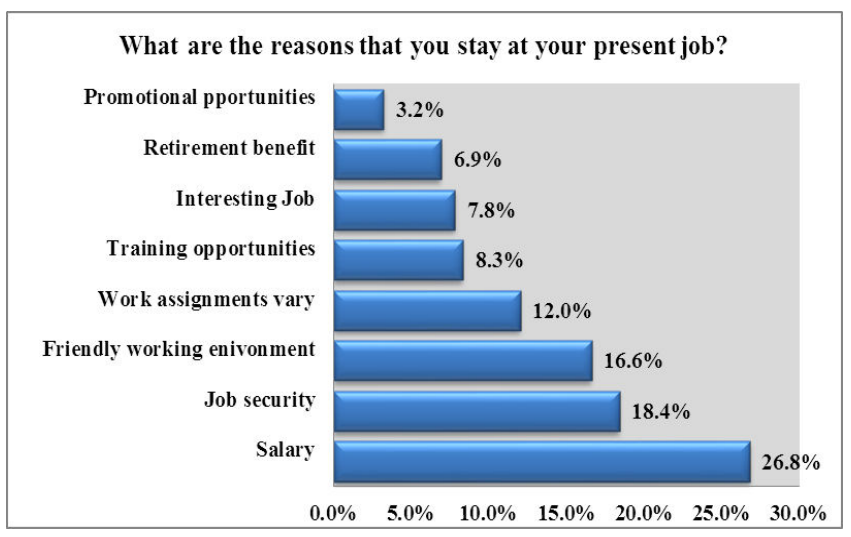

Figure 1: Job satisfaction factors in percentage (Q14)

Question 16: respondents were asked to give their opinion about the importance of employee motivation in their organisations and $70.5 \%$ of respondents are of the opinion that employee motivation is important in their organisations to enhance performance.

In question 19, participants were asked to indicate the factors that motivate them most or motivate them to do extra work. The results are in Figure 2 below. 
Figure 2: Results

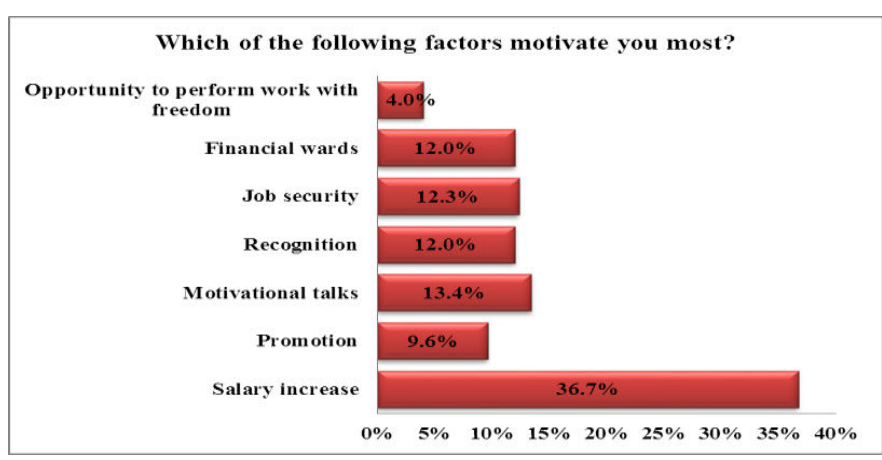

In question 22, participants were asked to give their opinion about the importance of training by the HRM department to enhance their performance in the organisation.

Table 5: Importance of training in relation to improving employee performance (Q22)

\begin{tabular}{|c|c|c|c|c|c|}
\hline \multicolumn{6}{|c|}{$\begin{array}{l}\text { How important to you is the training in relation to your } \\
\text { performance in your organization? }\end{array}$} \\
\hline & & $\begin{array}{l}\text { Freque } \\
\text { ncy }\end{array}$ & Percent & $\begin{array}{l}\text { Valid } \\
\text { Percen } \\
\text { t }\end{array}$ & $\begin{array}{l}\text { Cumulativ } \\
\text { e Percent }\end{array}$ \\
\hline \multirow[t]{5}{*}{ Valid } & Unimportant & 7 & 6.7 & 6.7 & 6.7 \\
\hline & Neutral & 17 & 16.2 & 16.2 & 22.9 \\
\hline & Important & 56 & 53.3 & 53.3 & 76.2 \\
\hline & $\begin{array}{l}\text { Very } \\
\text { important }\end{array}$ & 25 & 23.8 & 23.8 & 100.0 \\
\hline & Total & 105 & 100.0 & 100.0 & \\
\hline
\end{tabular}

In Table 5, the result demonstrates that $77.1 \%$ of the respondents agree that training arranged by the HRM department assists them in performing their job better.

The first objective is to find practical and suitable HRM practices for employee job performance, employee motivation, and employee satisfaction. The findings indicate that procedures by HR managers have been employed in order to select the right employee to the right position in the Lao hotel industry by: (1) screening application form, (2) conducting the job interviews (3) checking the background of the candidates (if the applicants have work experience for another organisation), (4) hiring decision, and (5) job offer at the right level for the candidate's qualifications to get the best performance from the employee and to motivate them by training programmes. Thus the HRM practices are in place in Laos's hotels and the main research question has been answered.

The second objective is to identify factors that motivate hotel employees to perform at high standard levels. The result of the study demonstrates that most of the respondents feel that their organisations create the conditions whereby they are motivated to work harder. In addition, the result indicates that the most influential factor that motivates the respondents to work harder is to increase their salary (Figure 2).

The third objective is factors that bring about a high level of job satisfaction among employees and the result reveals that the majority of respondents are satisfied and happy with their current work and organisational work conditions. The majority of the respondents point out that the main factor that brings about high level of job satisfaction is salary. The other two most influential factors that lead to employee satisfaction in the Lao hotel industry are job security and friendly working environment.

The fourth objective is to examine the influence of training on the employee's work performed in the organisation. The majority of respondents in the hotel industry recognise the importance of training in relation to their work performed in the organisation. Most of them feel that training has a positive influence on their work performed in the organisation.

The fifth objective is the impact of the financial incentives implemented by the organisation on employee performance. The study reveals that the financial incentives provided by the organisation have a positive impact on employee in other words the majority of hotel employees have no different opinion that financial incentives provided by their organisation motivate them to work harder.

The sixth and last objective is the relationship between satisfaction of employees and the salary paid by the organisation. The result indicates that there is a positive relationship between employee satisfaction and high pay/salary offered by the organisation.

\section{Managerial Implications and Recommendations}

The role of HRM is invaluable in the below points:

In the employee selection criteria, apart from considering qualifications, experience, knowledge, skills, and abilities of the candidates, the hotels should consider the candidates' attitudes, values, and personality to get person-organisation fit that can lead to organisational commitment and better performance.

The hotel should provide more training that is necessary for employees, especially a Customer service course and English language course in order to improve and increase their ability and better their performance at work.

The hotels should understand that apart from self-actualization needs, self-esteems needs, money is the most important factor that drives hotel employees to work harder and they should consider the factors to increase employees' job satisfaction which brings about an increase in employee commitment to the organisation and results in their organisational performance and satisfaction. 
The hotels should reconsider and develop fair compensation policies for all employees as it is more likely to result in employee satisfaction which leads to the increase of employees' work performance, higher level of employee commitment and higher retention levels.

The hotels should reconsider their organisational working environment, organisational rewards, flexible work arrangements, and their organisational promotion systems in order to ensure that there is a high level of employee motivation which results in an increase of employee work performance, and an improvement of organisational productivity.

\section{Conclusions}

This research study provides guidance and direction for the hotel industry in Laos to improve their performance and to have a competitive edge over their rivals in the market. Even if there are many factors that influence the organizational performance and the success of the organization, the effectiveness of HRM practices is one of the major components that indicate and determine the success of the hotel business. If the hotels carefully analyse and evaluate employee needs and align those needs with organizational goals, the hotels will get the desired results that might help them grow continuously and beneficially.

Apart from the effectiveness of HRM practices, the Lao hotels should consider other important components that lead to the success of their businesses and results in sustainable competitive advantage. For example, the effectiveness of financial management, the quality of customer service, the leadership style of the managers, cutting-edge technology, the design of the hotel and the effectiveness of a marketing strategy.

\section{Reference}

- Aksu, A. A. (2005). Defining training needs of five-star hotel personnel: an application in the antalya region of Turkey. Managerial auditing journal, 20(9), 945-953, CrossRef

- Armstrong, M. (2006). A handbook of human resource management practice (10th ed.). Pennsylvania, PA: Kogan Page Limited.

- Armstrong, M., \& Taylor, S. (2014). Armstrong's handbook of human resource management practice (13th ed.). London, UK: Kogan Page.

- Beardwell, J., \& Claydon, T. (2007). Human resource management: A contemporary approach (5th ed.). New York, NY: Prentice Hall/Financial Times.

- Boella, M., \& Goss-Turner, S. (2012). Human resource management in the hospitality industry. Retrieved from http://unitec.eblib.com.au/patron/FullRecord.aspx?p=27 0111

- Boxall, P., \& Purcell, J. (2011). Strategy and human resource management (3rd ed.). London, UK: Palgrave Macmillan.

- Bratton, J., \& Gold, J. (2012). Human resource management: Theory and practice (5th ed.). London, UK: Palgrave Macmillan.

- Business Dictionary. (2014). Data Analysis. Retrieved from

http://www.businessdictionary.com/definition/dataanalysis.html

- Chandan, J. S. (2009). Organizational behaviour (3rd ed.). New Delhi, India: Vikas Publishing House Pvt Limited.

- Cho, J., \& Trent, A. (2006). Validity in qualitative research revisited. Qualitative research, 6(3), 319-340, CrossRef

- Darwish, T. K. (2013). Strategic HRM and performance : Theory and practice. Retrieved from http://unitec.eblib.com.au/patron/FullRecord.aspx?p=12 20971

- Du Plessis, A.J (2015)(general editor)., Munyeka, W.., Chipunza, C., Samuel, M. O.,Naidoo, K., Keyser, E. \& Gura, M. HRM and ER in South Africa: contemporary theory and practice. Juta Publishers, Cape Town, South Africa.

- Du Plessis, A., Toh, W., \& Chen, J. (2013). Integrating leadership development, talent retention and knowledge management: HRM's role. International Journal of Contemporary Business Studies, 4(8), August: 43-55.

- Gerson, R. F. (2006). Achieving high performance: A research-based practical approach. Amherst, MA: HRD Press, Inc.

- Ghuman, K. (2010). Management: Concepts, practice \& cases. New Delhi, India: McGraw-Hill Education (India) Pvt Limited.

- Grigoroudis, E., \& Siskos, Y. (2010). Customer satisfaction evaluation: methods for measuring and implementing service quality. New York, NY: Springer, CrossRef

- Hayes, D. K., \& Ninemeier, J. D. (2009). Human resources management in the hospitality industry. New Jersey, NJ: John Wiley \& Sones, Inc.

- Holbeche, L. (2012). Aligning human resources and business strategy. Oxford, UK: Taylor \& Francis.

- Josten, E., \& Schalk, R. (2010). The effects of demotion on older and younger employees. Personnel Review, 39(2), 195-209, CrossRef

- Kothari, C. R. (2011). Research methodology: Methods and techniques (2nd ed.). New Delhi, India: New Age International (P) Limited.

- Lauby, S. J. (2005). Motivating employees. Virginia, VA: American Society for Training \& Development.

- $\quad$ Loedolff, P., Erasmus, B. J., Van, Z., Mda, M., \& Nel, P. S. (2013). Managing training and development in South Africa (6th ed.). Cape Town, South Africa: Oxford University Press.

- Macky, K., \& Wilson, M. (2013). Rewards, Remuneration and Performance: A Strategic Approach. Auckland, New Zealand: CCH New Zealand Limited.

- Mathis, R. L., \& Jackson, J. (2011). Human resource 
management: Essential perspectives (6th ed.). Mason, $\mathrm{OH}$ : Cengage Learning.

- McGuire, D., \& Jorgensen, K. M. (2010). Human resource development : Theory and practice. Retrieved from

http://unitec.eblib.com.au/patron/FullRecord.aspx?p=74 3572

- Mishra, M. N. (2009). Organisational behaviour. New Delhi, India: Vikas Publishing House.

- Muijs, D. (2010). Doing quantitative research in education with SPSS (2nd ed.). London, UK: SAGE Publications.

- Nahavandi, A., Denhardt, R. B., Denhardt, J. V., \& Aristigueta, M. P. (2014). Organizational behavior. London, UK: SAGE Publications.

- Neely, A. (2007). Business performance measurement: Unifying theory and integrating practice (2nd ed.). London, UK: Cambridge University Press, CrossRef

- $\quad$ Nel, P. S., Du Plessis, A., Fazey, M., Erwee, R., Pillay, S., Hearn Mackinnon, B., \& Millet, B. (2012). Human resource management in Australia and New Zealand. South Melbourne, Australia: Oxford University Press.

- Nel, P. S., Werner, A., Botha, C. J., Du Plessis, A. J., Mey, M., Ngalo, O., Poiat, P., Van Hoek, L. (2015). Human Resources Management (9th ed.). Cape Town, South Africa: Oxford University Press.

- $\quad$ Nel, P. S., Werner, A., Poisat, P., Du Plessis, A., \& Sono, T. (2011). Human resources management (8th ed.). Cape Town, South Africa: Oxford University Press.

- Nickson, D. (2013). Human resource management for hospitality and tourism industries (2nd ed.). New York, NY: Taylor \& Francis.

- Özbilgin, M., Groutsis, D., \& Harvey, W. (2014). International human resource management. New York, NY: Cambridge University Press.

- Pinder, C. C. (2014). Work motivation in organizational behavior (2nd ed.). New York, NY: Taylor \& Francis.

- $\quad$ Pullins, E. B., Haugtvedt, C. P., Dickson, P. R., Fine, L. M., \& Lewicki, R. J. (2000). Individual differences in intrinsic motivation and the use of cooperative negotiation tactics. Journal of Business \& Industrial Marketing, 15(7), 466-478, CrossRef

- Rao, S. V. (2008). Human resources management: text and cases (2nd ed.). New Delhi, India: Excel Books Press.

- Robbins, S. P., Odendaal, A., \& Roodt, G. (2007). Organisational behaviour: global and Southern African perspectives. Cape Town, South Africa: Maskew Miller Longman.

- Saiyadain, M. S. (2003). Organizational behaviour. New Delhi, India: Tata McGraw-Hill Education.

- Snell, S., \& Bohlander, G. (2012). Managing human resources (16th ed.). New York, NY: Cengage Learning.

- $\quad$ St-Onge, S., Morin, D., Bellehumeur, M., \& Dupuis, F. (2009). Managers' motivation to evaluate subordinate performance. Qualitative Research in Organizations and
Management: An International Journal, 4(3), 273-293, CrossRef

- Stone, R. J. (2013). Managing human resources ( 4th ed.). Milton, Qld: John Wiley and Sons, CrossRef, CrossRef

- Sustainable Tourism Development Project In Lao PDR. (2009). Development of the project's human resource development action plan (2009-2014):Contract packages to support implementation of the plan (20042009) and contract packages to support implementation of the plan. Vientiane, Laos. Retrieved from http://www.stdplaos.com/downloads/technical_reports/ part4/GMS-

STDP\%20in\%20Lao\%20PDR_\%20Project $\% 27$ s $\% 20 \mathrm{H}$ RD\%20Action\%20Plan.pdf.

- Watson, S. (2008). Where are we now? A review of management development issues in the hospitality and tourism sector: implications for talent management. International Journal of Contemporary Hospitality Management, 20(7), 758-780, CrossRef

- Wicker, D. (2011). Job satisfaction: Fact or fiction. Bloomington, IN: AuthorHouse.

- Wilton, N. (2011). An introduction to human resource management. UK: SAGE Publications.

- $\quad$ Yamauchi, S., \& Lee, D. (1999). Tourism development in the Lao People's Democratic Republic. Retrieved from

http://www.un.org/esa/desa/papers/1999/esa99dp9.pdf 